\title{
Development experience of ore extraction and traffic simulation system in potash mines - bundled software "Рудопоток"
}

\author{
Gleb Chudinov \\ Perm State National Research University \\ Perm, Russian Federation \\ e-mail: gleb.chud@gmail.com
}

\author{
E.B. Zamyatina (research supervisor) \\ Perm State National Research University \\ Perm, Russian Federation
}

\begin{abstract}
Development experience of ore traffic and extraction simulation system in underground part of potash mines is reviewed. Distinctive features of suggested simulation model (combine complex extraction, using conveyor transport and transfer point in continuous ore traffic simulation) are represented. Implementation features of bundled software "Рудопоток" are considered.
\end{abstract}

Keywords: simulation model, simulation system, potash, mine, extraction, conveyor, ore traffic

\section{INTRODUCTION}

The final goal of potash mining company is increasing extent of mineral production with simultaneous decreasing of its expenses. Considerable contribution in total bottom-line cost is endowed by ore extraction and transportation in mines' underground parts. In connection with this problem of optimal mining planning become urgent. It includes tasks for guaranteeing minimal-required mineral content (quality), continual conveyor workload and uniform ore arrival to shafts with total decreasing transportation costs. Additional tasks for solving problem are selection optimal sizes and places for bunkers in transfer points, conveyor transport estimation, determination for transport scheme and layer way of ore extraction.

Significant to note, classical task of statistical rough estimation for combine complex production rates was researched and solved in mining literature, example [1]. But for interactively solving the problem (in dynamic) it needs simulation. Though according to author investigations, also [2] - most of complex models are from 1980s and technically turned old because of computing machinery' and information technologies rapid development. Modern researches [3] are devoted to coal mines and explore different aspects, laying aside questions of ore quality composition, its extraction in mining sites, and don't take into account conveyor transport specific and ore flow continuous nature.

The development of detailed simulation model and simulation experiment for ore extraction and transportation in underground part of potash mines and its software implementation (bundled software "Рудопоток") have been progressing since 2008 year [4]. The project is elaborating in Aerology and Thermal Physics Laboratory of Mining Institute
UrB of RAS and it includes the investigation results of Computer Science Department[5] (Perm State University).

The paper demonstrates key features (generic aspects) and main specific characteristics for developed program model (via bundled software) of ore extraction (layered, headingand-stall method by combine complexes) and transportation using conveyors and transfer points in underground part of potash mines. Suggested model have been verified, validated, calibrated and have been approved on transportation network of mine БКПРУ-4. The methodologies for determination of optimal parameters for transport equipment have been developed.

\section{SIMULATION MODEL AND ITS FEATURES}

Most of known models in freight (ore) flow [1], [2], [3] are simplified or investigated only part of needful aspects. Often, they don't take ore mineral quality (composition) into account, it's impossible to manage conveyor speed and power consumption and to optimize these parameters. Ore movement on conveyors isn't full and is performed without taking into account the cross-sectional profile of the conveyor belt. Mining sites are replaced with aggregates usually.

One of ways to solve the problem is to use agent oriented paradigm in relation to simulation [6]. In this case simulation model of ore extraction in mine is presented as an extended object scheme for conveyor transport. Structure for the transport network - blocks, conveyors, transfer points and relations between them - is specified in program as user input (Fig. 1).

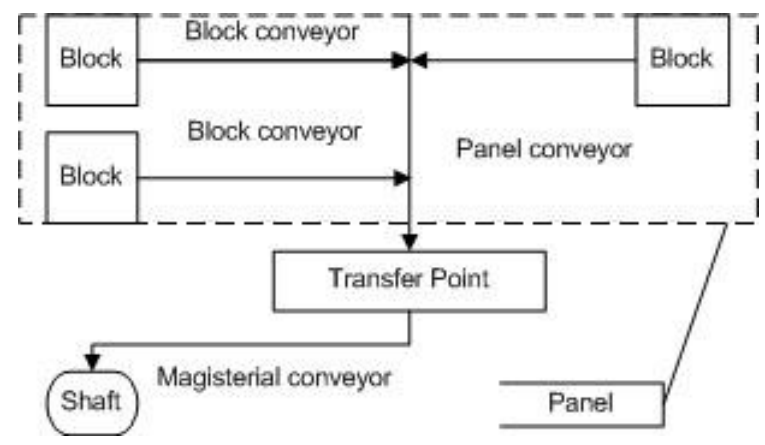

Figure 1. Model of mine transport scheme - common components 


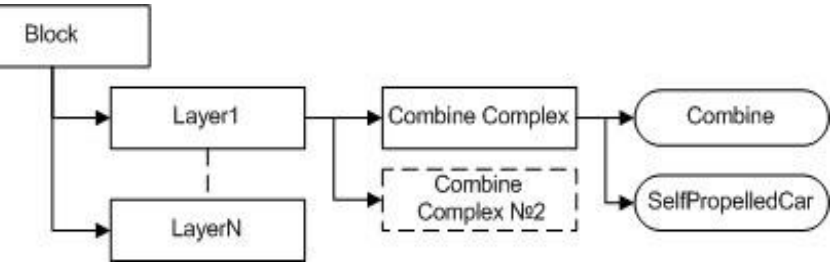

Figure 2. Component structure of mining site (block)

User inputs parameters: belt width, length, speed; side rollers angle of inclination and etc. - for conveyors. Transfer points (TP) are equipped with discharge devices (DD) with specified productivity for each. Mining sites are separated on native parts - multiple layers and combine complexes (Fig. 2). Each unit has its own characteristics. Model takes into account combine complexes' working order (plan), different equipment types (models) and physical restrictions for them; also sizes and frequency of stall and ore passes placement (layout); technical and organizational idle times. All these parameters and some others influence on simulation process and output results.

Important feature is ore transportation on conveyors with layered holding (Fig. 3) and taking cross-section belt profile (Fig. 4) into account. Model implements ore continuous flow transportation process in discrete model (bunker filling and emptying are subject to ratio of DD bandwidths and incoming ore rates). It implements ore proportional unloading on multiple conveyors according to realistic physical behavior and constraints.

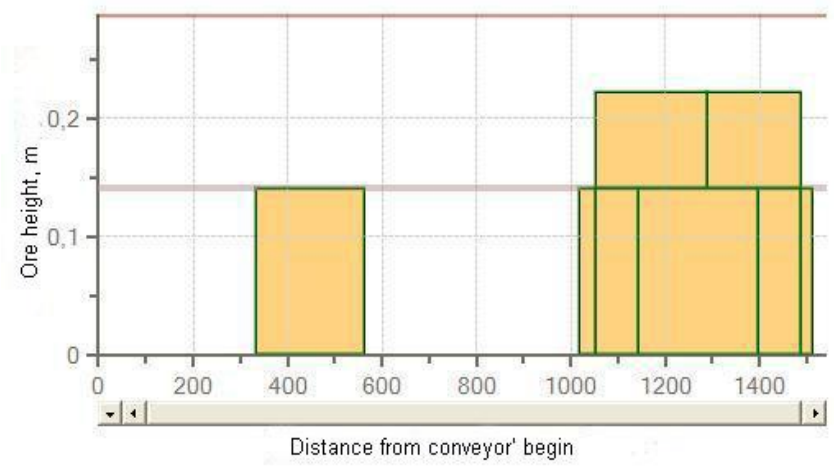

Figure 3. Ore width/height distribution on conveyor belt

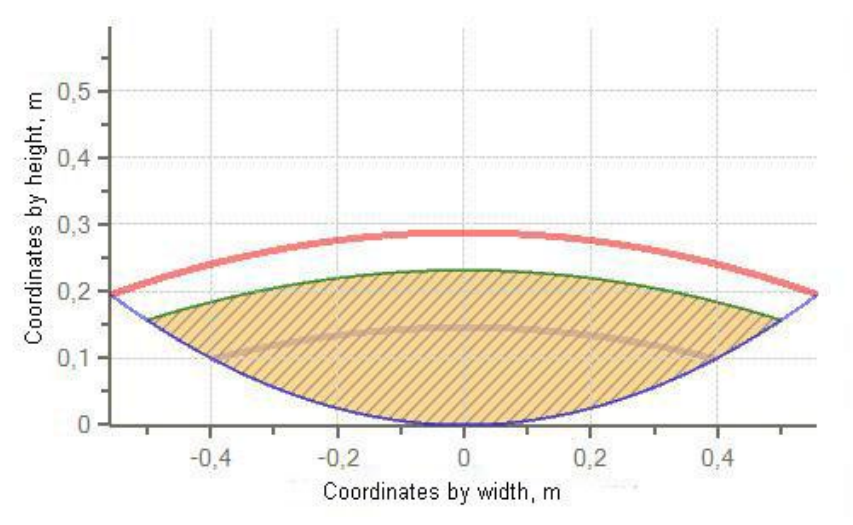

Figure 4. Conveyor belt cross-section profile
Ore mass' mineral composition quality are taken into consideration, it's computed during excavation process in mined layers in block. Model keeps track of mineral content in the cases of ore mixing in bunkers and as result of ore layering on panel (magisterial) conveyors.

Methodology for computation average-required conveyor productivity and minimal-required TP bunker volumes are developed on the base of imitation experiments' series on calibrated model (natural measurements were executed for defining accurate combine complex operations' duration). This methods use mean equipment workload for the time of all simulations running (Fig. 5). Simulation engine takes optimal value for each iteration, and maximum of them from experiments series as final result for equipment.

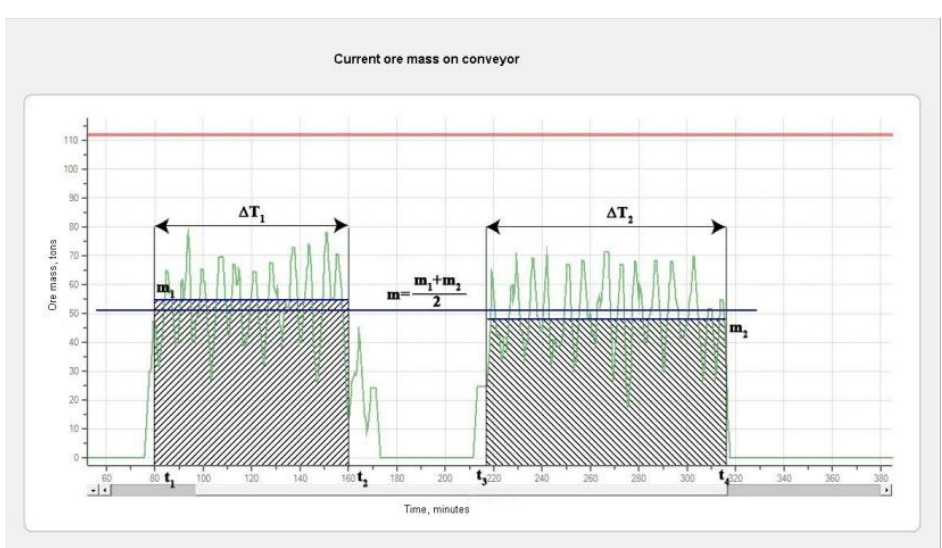

Figure 5. Determination of mean ore mass along conveyor belt

\section{High LEVEL ARCHITECTURE VIEW OF "РУДОПОTOK" SOFTWARE}

Completed program implementation is interaction along time among three main modules by areas of responsibility: graphical interface (GI), data persistence and simulation model (SM). In turn GI and SM are divided into lesser components.

Graphical interface ensures common user data editing (definition of transport network structure and its main components - blocks, conveyors and transfer points, interconnections between them; parameters of model equipment). Besides, after series of imitational experiments results are displayed into diagrams of ore mass and its mineral composition quality over time, and some others. Animation for processes of ore extraction and transportation over all mine are implemented on basis of received historical data from completed experiments (Fig. 6).

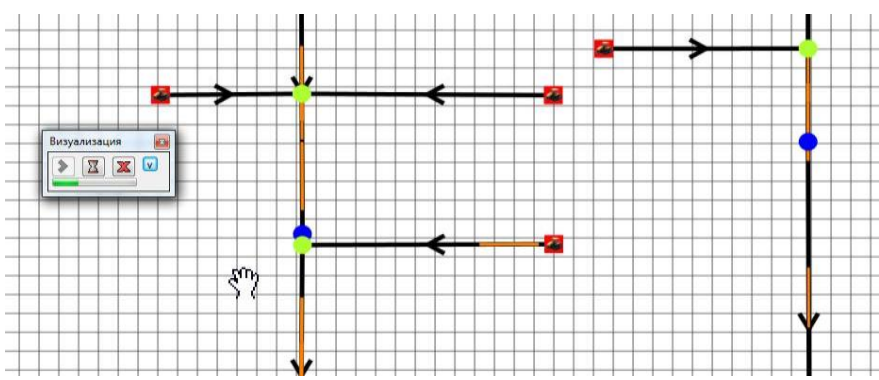

Figure 6. Ore extraction animation on all transport network, blocks disabled 
Statistics gathering module is represented by classes for aggregation and storing states of objects over time and gathering statistical information after simulation completion. Basis for optimization is data linearization, when only begin and end of line sections are retained for linear-changing parameters (removing intermediate points as unnecessary) (Fig. 7).
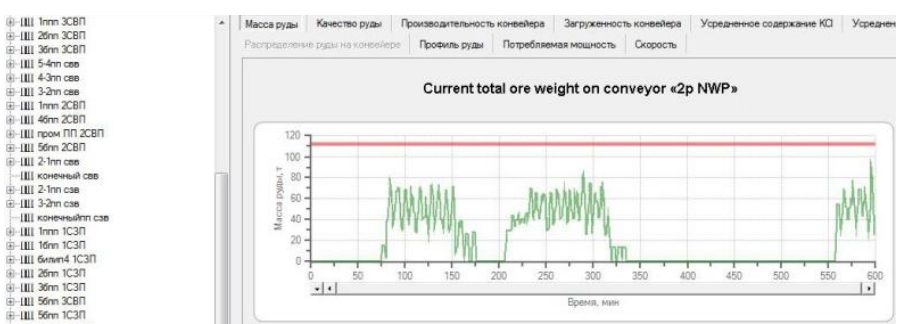

Figure 7. Ore extraction animation on all transport network, blocks disabled

Simulation model consists of domain classes (Fig. 8), time advancement system (scheduler) and statistics gathering module. Domain implements main conception classes such as block, conveyor, transferring point. Equipment behavior along time (combine, self-propelled car) is simulated indirectly on basis of state diagrams (work without outer influence) and activity diagrams (equipment interaction, for example, ore transfer). Time advancement system consists of scheduler, where discrete event algorithm for time advancement with constant and variable step (with possible sub steps) is implemented.

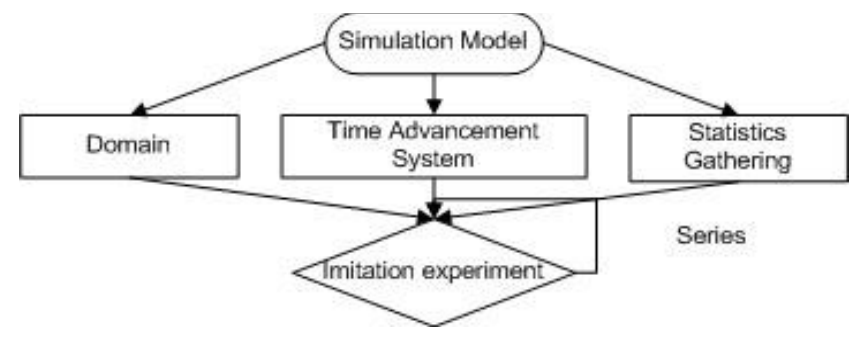

Figure 8. Simulation model main components

\section{CONCLUSION AND EXPERIMENTAL RESULTS}

Thus, object imitational model of ore extraction and transportation in underground parts of potash mines is developed. Its verification, validation and calibration have been made. On model basis methods for estimation of equipment optimal parameters (TP bunker volume, conveyor belt bandwidth) are suggested and developed. Model was implemented as bundled computation software "Рудопоток", which affords means for creating (building), running and analyzing of transport networks (existing or only under construction); animation for processes of ore extraction and transportation in all over the mine in whole. Experimental check has been accomplished on transport scheme for mine БКПРУ-4 on 2010 year.

\section{REFERENCES.}

[1] Лыхин П.А. Добыча калийных солей. (In Russian) URL: http://www.mi-perm.ru/authors/lyhin/b1_text.htm\#s

[2] Панасюк И.И. Имитационное моделирование организации рудопотока и управления затратами горнорудного предприятия: дис. канд. экон. наук : 08.00.13 СПб., 2005, 263 с. (In Russian)

[3] Конюх В.Л. Имитационное моделирование системы подземного транспортирования / В. Л.Конюх // Проблемы информатики, 2010. - №3. - C. 43-53. (In Russian)

[4] Круглов Ю.В., Мальцев М.С., Чудинов Г.В. Имитационное моделирвоание горных работ и рудопотоков в калийных рудниках ОАО «Уралалий».// Горный журнал, 2011.- № 11 .- С. 20-22 (in Russian)

[5] Замятина Е.Б., Чудинов Г.В. Разработка и использование программных средств для построения и исследования агентных имитационных моделей. / Е.Б. Замятина, Г.В. Чудинов // Вестник пермского университета. Математика, механика, информатика, 2010, №2(2), C. 80 - 84. (in Russian)

[6] Macal C.M., North M.J. Agent based modeling and simulation / C.M. Macal, M.J. North // In the Proceedings of the 2009 Winter Simulation Conference, ed. Rossetti M. D., Hill R. R., Johansson B., Dunkin A., Ingalls R.G., 2009. P. 86-98. 